\title{
Pemanfaatan Lahan Pekarangan Melalui Sistem Vertikultur Budidaya Sayuran Kelompok Tani Sinar Manumuti Desa Upfaon
}

\author{
Lambertus Nesi Bria $^{1)}$, Boanerges Putra Sipayung ${ }^{2}$, Wilda Lumban Tobing ${ }^{3)}$ \\ Universitas Timor ${ }^{1), 2), 3)}$ \\ Email: wildatob14@gmail.com ${ }^{3)}$

\begin{tabular}{|l|l|l}
\hline Dikirim: 26-11-2020 & Direvisi: 24-02-2020 & Diterbitkan: 28-02-2021
\end{tabular}

\begin{abstract}
ABSTRAK
Tujuan dari pengabdian adalah menjadikan vertikultur sebagai alternatif keterbatasan lahan yang dimiliki oleh masyarakat dan persediaan air yang sedikit dalam budidaya sayuran.Kegiatan pengabdian dilakukan di lahan pekarangan rumah anggota kelompok tani Sinar Manumuti Desa Upfaon, Biboki Selatan, Kabupaten Timor Tengah Utara. Kegiatan ini berlangsung selama 2 (dua) bulan (Oktober-Desember 2020). Metode yang digunakan pada pengabdian ini adalah penyuluhan dan pelatihan oleh tim pengabdian sampai kelompok tani terampil dan mandiri yang terdiri dari beberapa kegiatan antara lain : 1) sosialisasi dan pelatihan pembuatan vertikultur; 2) sosialisasi dan pelatihan penggunaan media tanam; 3) sosialisasi dan pelatihan penyemaian benih; 4) sosialisasi dan pelatihan penanaman pada vertikultur; dan 5)sosialisasi dan pelatihan perawatan tanaman. Berdasarkan hasil kegiatan pengabdian di kelompok tani Sinar Manumuti di Desa Upfaon dapat disimpukan bahwa memanfaatkan lahan pekarangan melalui sistem tanam vertikultur pada budidaya sayuran memberikan solusi bagi lahan dan ketersediaan air yang terbatas, pengabdian telah memberi pengetahuan baru kepada masyarakat mengenai vertikultur dengan banyak kelebihannya, dan anggota Kelompok Tani Sinar Manumuti dapat menghemat pengeluaran belanja kebutuhan pangan keluarga tanpa harus membeli.
\end{abstract}

Kata Kunci : Budidaya Sayuran, Kelompok Tani Sinar Manumuti, Lahan Pekarangan, Vertikultur.

\section{ABSTRACT}

The purpose of this community service is to make verticulture an alternative to the limited land owned by the community and a small supply of water for vegetable cultivation. The community service activity was carried out in the garden of the Sinar Manumuti farmer's, Upfaon Village North Central Timor Regency. This activity lasts for 2 (two) months (October-December 2020). The method used in this service is counseling and training by the service team to skilled and independent farmer groups which consists of several activities, among others: 1) socialization and training in making verticulture; 2) socialization and training on the use of planting media; 3) socialization and seeding training; 4) socialization and training of planting in verticulture; and 5) socialization and training in plant care. Based on the results of community service activities in the Sinar Manumuti farmer's in Upfaon Village, it can be concluded that utilizing their yards through the verticulture planting system in vegetable cultivation provides solutions for limited land and water availability, dedication has provided new knowledge to the community about verticulture with many advantages, and members Sinar Manumuti Farmer Group can save on family food expenses without having to buy.

Key Words : Garden, Sinar Manumuti Farmer's, Vegetable Cultivation, Verticulture 


\section{PENDAHULUAN}

Kelompok tani Sinar Manumuti adalah salah satu kelompok tani penghasil sayuran di Desa Upfaon, Kabupaten Timor Tengah Utara (TTU). Desa ini terletak di Kecamatan Biboki Selatan. Penghasilan utama dari sebagian besar masyarakat berasal dari bertani/bercocok tanam. Semakin bertambah jumlah penduduk maka kebutuhan pangan dan lahan juga meningkat, sehingga lahan sangat dibutuhkah masyarakat untuk usatahatani. Tetapi lahan bertani yang dimiliki masyarakat tidak luas, hanya berupa lahan pekarangan saja. Selama ini, masyarakat menggunakan lahan milik orang lain untuk dapat bercocok tanam dengan sistem bagi hasil dengan pemilik lahan. Adanya lahan pekarangan dari setiap petani menjadi potensi dalam pemenuhan pangan keluarga. Oleh sebab itu, dengan adanya vertikultur dapat mengurangi keterbatasan masyarakat dalam budidaya sayuran. Vertikultur merupakan teknik budidaya tanaman secara tegak dan media yang digunakan dalam hal ini adalah pipa paralon sehingga efisien di lahan yang terbatas dan media dapat digunakan kembali setelah panen.

Nusa Tenggara Timur (NTT) dicirikan dengan wilayah berlahan kering. Menurut Ritung et al. (2015), Provinsi Nusa Tenggara Barat (NTB) dan NTTmemiliki lahan kering dengan 48,2\% atau sekitar 5,2 juta ha. Lahan kering juga terdapat pada Desa Upfaon sehingga penggunaannya dalam lahan pertanian perlu pengelolaan yang lebih baik karena memiliki solum yang dangkal dan berbatu tetapi tetap dimanfaatkan masyarakat untuk usahataninya walaupun produktivitasnya lebih rendah. Dengan kondisi demikian, persediaan air untuk bertani juga perlu diperhatikan. Diketahui curah hujan di Pulau Timor sepanjang tahun 2020 sangat rendah sehingga hal ini mengakibatkan kelompok tani Sinar Manumuti tidak melakukan kegiatan budidaya. Jika untuk kebutuhan konsumsi sayuran maka masyarakat harus membeli ke pasar.

Adanya vertikutur diharapkan menjadi nilai tambah bagi masyarakat menggunakan lahan pribadi dan hasilnya tidak dibagi dengan orang lain. Dalam penggunaannya, media tanam dapat diganti atau dipindah-pindah setelah masa panen selesai. Hal ini membuat kemudahan bagi petani yang tidak perlu melakukan pengolahan tanah yang lebih berat lagi, bisa memodifikasi sendiri media tanamnya bergantung kepada bahan organik yang tersedia dan tanaman lebih terbebas dari hama dan penyakit. Selain itu, pada kondisi saat ini dengan curah hujan yang rendah, melalui sistem vertikultur dapat menjadi solusi bagi petani karena tidak membutuhkan air yang banyak.Tujuan dari kegiatan ini adalah menjadikan vertikultur sebagai alternatif keterbatasan lahan yang dimiliki oleh masyarakat dan persediaan air yang sedikit dalam budidaya sayuran.

\section{METODE}

Kegiatan pengabdian dilakukan di lahan pekarangan rumah anggota kelompok tani Sinar Manumuti Desa Upfaon, Kecamatan Biboki Selatan, Kabupaten Timor Tengah Utara, Nusa Tenggara Timur. Kegiatan ini berlangsung selama 2 (dua) bulan (Oktober-Desember 2020). Metode yang digunakan pada pengabdian ini adalah penyuluhan dan pelatihan oleh tim pengabdian sampai kelompok tani terampil dan mandiri dengan beberapa kegiatan, antara lain:

1. Sosialisasi dan pelatihan pembuatan vertikultur 
Vertikultur menggunakan bahan pipa paralon yang dibuat lubang-lubang tanam yang sudah diatur jaraknya. Terdapat 12 lubang tanam dalam 1 meter paralon ukuran 4 dim.

2. Sosialisasi dan pelatihan penggunaan media tanam

Media tanam yang digunakan dengan memafaatkan limbah kegiatan pertanian yang belum terurai yang dijadikan bahan organik. Inkubasi dilakukan selama 2 minggu kemudian dicampurkan ke tanah sebagai media tanam. Selanjutnya diisi ke wadah vertikultur.

3. Sosialisasi dan pelatihan penyemaian benih Penyemaian dilakukan menggunakan lahan pekarangan dengan membuat bedengan berukuran $1 \mathrm{~m}$ x $3 \mathrm{~m}$ dengan menaburkan benih sayuran selama 2 minggu yang ditutup kain tipis dan transparan.

4. Sosialisasi dan pelatihan penanaman pada vertikultur Benih yang sudah disemai selama 2 minggu dipindahkan ke setiap lubang tanam yang telah dibuat sampai waktu panen (35 HST).

5. Sosialisasi dan pelatihan perawatan tanaman

Untuk perawatan pada sistem vertikultur digunakan paranet untuk mencegah hama dan patogen penyakit yang dapat menyerang tanaman. Tanaman perlu disiram setiap hari dengan cara cukup menyemprotkan air ke setiap tanaman.

\section{HASIL DAN PEMBAHASAN}

Berdasarkan hasil kegiatan pengabdian di kelompok tani Sinar Manumuti di Desa Upfaon, pemanfaatan lahan pekarangan melalui vertikultur media paralon dapat dijadikan alternatif budidaya sayuran pada kondisi lahan terbatas, kurangnya persediaan air dan pengelolaan lahan kering yang cukup berat untuk dijadikan lahan pertanian. Selama ini vertikultur dikenal sebagai sistem pertanian kota dengan lahan yang sempit akibat bertambahnya kepadatan penduduk di kota dan sebagai nilai estetika di areal tempat tinggal. Mariyam et al. (2014) menyatakan bahwa sistem ini cocok diterapkan di lahan-lahan sempit atau pada pemukiman yang padat penduduk. Penanaman secara vertikultur sesuai dengan konsep Urban Farming yang saat ini tengah banyak diperbincangkan. Berdasarkan informasi yang diperoleh dari Indonesia Berkebun (2015), konsep Urban Farming adalah metode bercocok tanam di wilayah perkotaan yang ukuran lahannya relatif sempit dengan teknik bertanam khusus seperti vertikultur, hidroponik dan aquaponik. Namun kegunaan budidaya menggunakan sistem tanam vertikultur semakin berkembang. Pulau Timor dengan ciri lahan keringnya dapat menjadikan vertikultur di lahan pakarangan untuk mengatasi beberapa hal yang menjadi masalah seperti persediaan air yang terbatas. Samiati et al.(2012) menyatakan bahwa air bagi tanaman merupakan sumber daya yang penting karena hampir semua proses fisika, kimia dan biologi di dalam tanah serta proses fisiologis tanaman tidak akan dapat berlangsung secara optimal tanpa ketersediaan air yang memadai. Menurut Riyanti (2011), kebutuhan air tanaman untuk pertumbuhan merupakan jumlah air yang digunakan oleh tanaman untuk tumbuh dengan normal. Sehingga adanya vertikultur dapat mengefisiensikan kebutuhan air dibandingkan harus menanam di bedengan dan memudahkan pengelolaan lahan kering untuk kegiatan pertanian. 
Kegiatan pengabdian ini dimulai dari persiapan wadah tanam vertikultur. Pelaksanaan dimulai dari pengenalan masing-masing alat yang digunakan, penentuan titik/lubang tanam dan jaraknya, pembuatan lubang tanam sampai peletakan wadah vertikultur. Setiap anggota kelompok tani mendapatkan 12 pipa vertikultur dengan ukuran panjang pipa $1 \mathrm{~m}$ dan 12 lubang tanam. Dari kegiatan ini, masyarakat telah mengetahui dan telah terampil dalam membuat wadah vertikultur yang digunakan sebagai wadah penanaman sayuran. Selain itu, masyarakat menyadari banyaknya keuntungan menggunakan sistem penanaman melalui vertikultur media paralon yang dapat dilihat pada Gambar 1 dan Gambar 4.

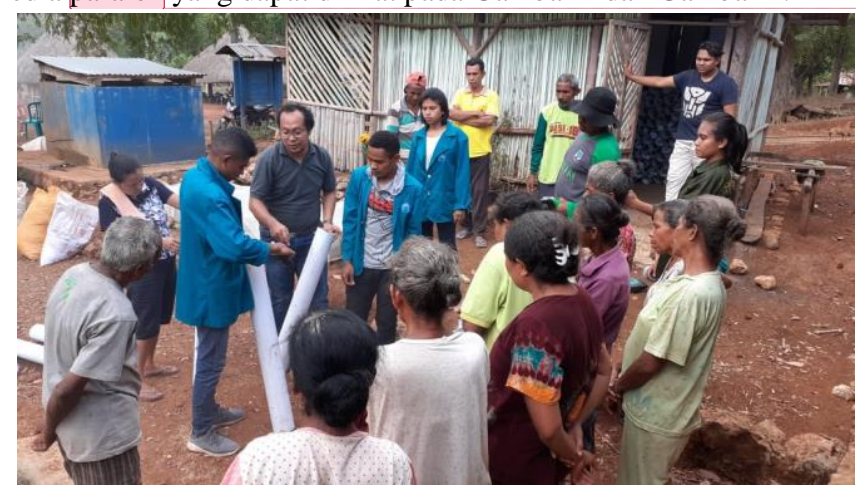

Gambar 1. Sosialisasi dan Pelatihan Pembuatan Pipa Vertikultur

Sosialisasi dan pelatihan persiapan media tanam dilakukan bersamaan dengan penyiapan pipa paralon vertikultur karena media harus diinkubasi sebelum dicampurkan ke tanah. Bahan yang digunakan adalah limbah hasil pertanian berupa sekam padi yang menumpuk karena tidak digunakan. Bahan ini dapat dijadikan arang sekam sebagai pembenah tanah. Menurut Glaser (2001), bahan ini dapat dijadikan pembenah tanah lahan kering. Gani (2009) menambahkan bahan tersebut berpotensi meningkatkan C-tanah secara berkelanjutan, retensi air dan hara dalam tanah. Arang sekam ini diinkubasi selama 2 minggu sebelum dicampurkan dengan tanah. Pencampuran dilakukan saat akan dimasukkan ke dalam pipa dengan perbandingan tanah dan arang sekam 1:2. Berdasarkan kegiatan ini, masyarakat dapat memanfaatkan limbah hasil pertanian yang berpotensi dijadikan bahan pembenah tanah. 


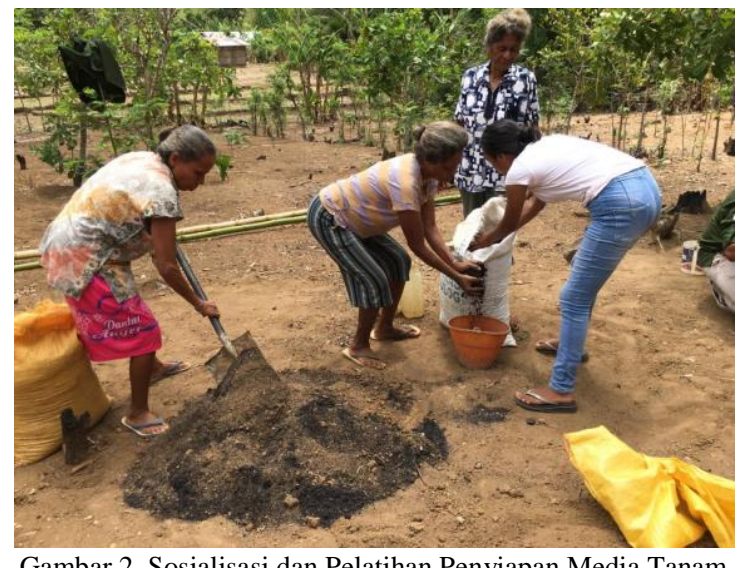

Gambar 2. Sosialisasi dan Pelatihan Penyiapan Media Tanam

Sosialisasi dan pelatihan penyemaian benih dilakukan juga bersamaan dengan penyiapan pipa paralon sebagai wadah tanam sistem vertikultur dan penyiapan media tanam. Benih sayuran disemai pada bedengan selama 2 minggu. Selama proses penyemaian, benih disiram saat kondisinya tidak terlalu lembab, penyemaian di bedengan ini juga membutuhkan penutup/naungan dari kain transparan berlubang untuk menjaga tanaman dari serangan luar. Dari hasil kegiatan ini, masyarakat mengetahui cara penyemaian benih sayuran yang baik.

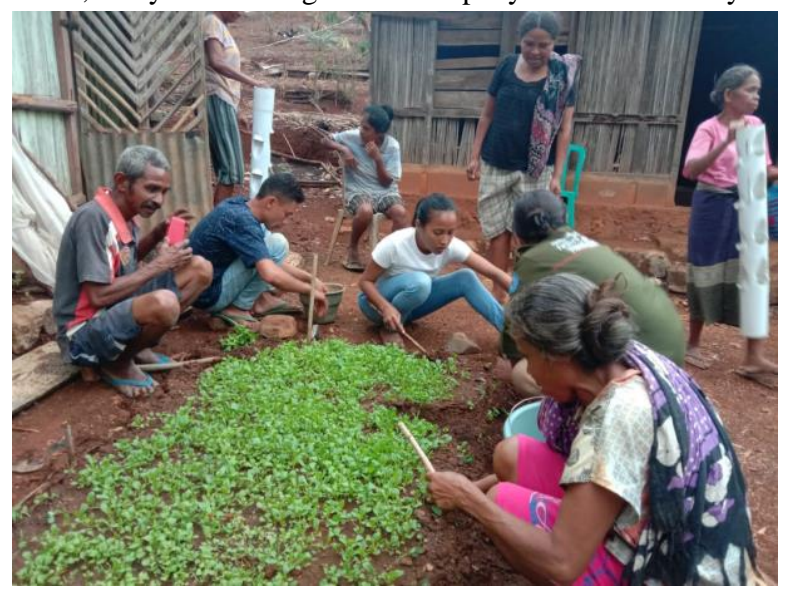

Gambar 3. Sosialisasi dan Pelatihan Memilih Tanaman

Sosialisasi dan pelatihan penanaman dilakukan dengan memperhatikan beberapa hal sebelumnya seperti kepadatan media di dalam pipa, membuat lubang tanam pada lubang pipa yang telah dibuat, memilih tanaman yang sehat, pemindahan tanaman ke dalam lubang pipa vertikultur. Masing-masing lubang tanam diisi dengan 1 tanaman. Berdasarkan kegiatan ini, kelompok tani Sinar Manumuti telah mengetahui teknik dan hal-hal yang perlu diperhatikan dalam pemindahan tanaman yang telah disemai ke dalam lubang tanam pipa paralon yang 
dijadikan wadah vertikultur. Selanjutnya pemanenan dilakukan oleh masyarakat bersamasama dengan tim pengabdian setelah tanaman berumur 35 HST.

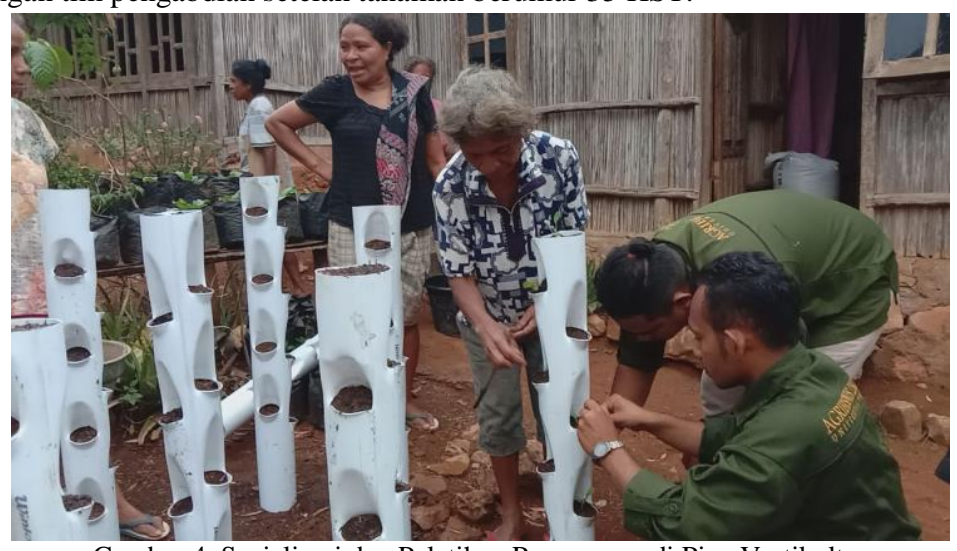

Gambar 4. Sosialisasi dan Pelatihan Penanaman di Pipa Vertikultur

Sosialisasi dan pelatihan perawatan tanaman dengan membuat naungan dari paranet. Salah satu kelebihan vertikultur ini memudahkan perawatan tanaman karena tidak memerlukan banyak waktu dan tenaga. Namun untuk lebih memudahkan perawatan, masingmasing pekarangan yang digunakan sebagai areal yang ditanami dikelilingi paranet sampai pada naungannya. Untuk penyiraman, dilakukan setiap hari hanya dengan cara menyemprotkan air ke bagian tanaman, saat kondisinya masih lembab maka penyiraman tidak perlu dilakukan. Berdasarkan kegiatan ini, kelompok tani Sinar Manumuti dapat mengetahui kemudahan perawatan menggunakan sistem tanam vertikultur dan mengetahui efisiensi penggunaan air jika dilakukan penanaman sistem vertikultur.

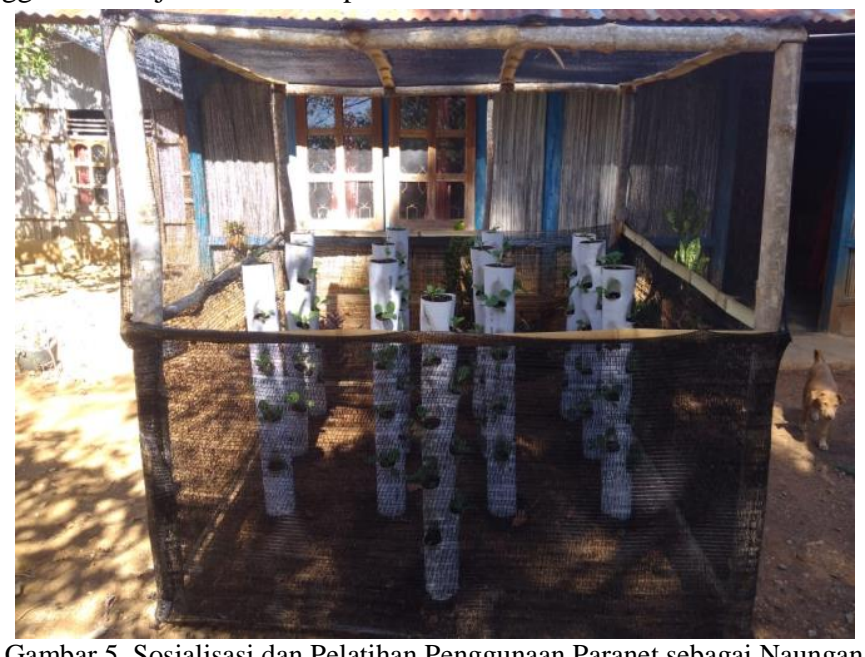

Gambar 5. Sosialisasi dan Pelatihan Penggunaan Paranet sebagai Naungan 
Hasil pelaksanaan program ini, masyarakat di Desa Upfaon menginginkan kerberlanjutan kegiatan penanaman melalui sistem vertikultur sebagai upaya menyediakan sayuran terutama pada kondisi lahan dan ketersediaan air yang terbatas. Adanya kegiatan ini, masyarakat dapat lebih menghemat pengeluaran pembelajaan rumah tangga karena tidak perlu membeli sayur lagi di pasar. Dengan sistem tanam vertikultur ini juga, anggota kelompok tani akan melakukan usahatani sayuran sepanjang tahun karena akses air yang dekat dan jumlah air lebih mudah dikontrol dari pada dilakukan di bedengan.

\section{SIMPULAN}

Berdasarkan hasil yang telah dicapai, kegiatan pengabidan di Kelompok Tani Sinar Manumuti dapat disimpulkan bahwa:

1. Kegiatan memanfaatkan lahan pekarangan melalui sistem tanam vertikultur pada budidaya sayuran memberikan solusi bagi lahan dan ketersediaan air yang terbatas.

2. Kegiatan pengabdian telah memberi pengetahuan baru kepada masyarakat mengenai vertikultur dengan banyak kelebihannya.

3. Kelompok Tani Sinar Manumuti dapat menghemat pengeluaran belanja kebutuhan pangan keluarga tanpa harus membeli.

\section{UCAPAN TERIMA KASIH}

Ucapan terima kasih disampaikan kepada Kementerian Pendidikan dan Kebudayaan melalui ProgramHolistik Pembinaan dan Pemberdayaan Desa (PHP2D) yang telah mendanai pengabdian kepada masyarakat ini. Terima kasih juga kepada Kelompok Tani Sinar Manumuti Desa Upfaon, Kecamatan Biboki Selatan yang telah bersedia dan berpartisipasi atas terlaksananya kegiatan PHP2D.

\section{DAFTAR PUSTAKA}

Gani A. 2009. Potensi Arang Hayati (Biochar) sebagai Komponen Teknologi Perbaikan Produktivitas Lahan Pertanian. Vol. 31, No. 6.

Glaser, B. 2001. The terra preta phenomenon: A model for sustainable agriculture in the humic tropic. DieNaturwissenschaften 88:37-4.

Indonesia Berkebun. 2015. Urban Farming ala Indonesia Berkebun. PT Agro Media Pustaka, Jakarta. http://books.google.co.id/ (Diakses pada tanggal 26 November 2020).

Mariyam, S., T. Rahayu dan Budiwati. 2014. Implementasi ECO-Education di Sekolah Perkotaan Melalui Budidaya Vertikultur Tanaman Hortikultura Organik. Jurnal Inotek. 18(1) : 28-38.

Ritung S, Suryani E, Subardja D, Sukarman, Nugroho K, Suparto, Hikmatullah, Mulyani A, Tafakresnanto C, Sulaeman Y, Subandiono RE, Wahyunto, Ponidi, Prasojo N, Suryana U, Hidayat H, Priyono A, Supriatna W. 2015. Husen et al. (Eds) Sumberdaya Lahan Pertanian Indonesia: Luas, Penyebaran, dan Potensi Ketersediaan. Badan Penelitian dan Pengembangan Penelitian. Jakarta, IAARD Press. $98 \mathrm{Hlm}$.

Riyanti, H. 2011. Pengaruh Volume Irigasi pada Berbagai Fase Tumbuh pada Pertumbuhan Melon (Cucumis melo L.) dengan Sistem Hidroponik. Skripsi (Publikasi). Departemen Agronomi dan Hortikultura. Fakultas Pertanian. Institut Pertanian Bogor. Bogor.

Samiati, A. Bahrun dan L.O. Safuan. 2012. Pengaruh Takaran Mulsa terhadap Pertumbuhan dan Produksi Sawi (Brassica juncea L.). Jurnal Penelitian Agronomi. 1(2) : 121-125 